УДК 378.14:78:7

DOI https://doi.org/10.52726/as.pedagogy/2021.3.2.7

\title{
Л. Л. ОРДІНА
}

кандидат педагогічних наук, доцент,

доцент кафедри соиіально-гуманітарних дисииплін,

Білочерківський національний аграрний університет,

м. Біла Церква, Київська область, Україна

Електронна пошта: Larisaordina@ukr.net

http://orcid.org/0000-0003-4127-6225

\section{ВПЛИВ УКРАЇНСЬКОГО МИСТЕЦТВА НА РОЗВИТОК ЕСТЕТИЧНОЇ КУЛЬТУРИ СТУДЕНТІВ У ЗАКЛАДАХ ВИЩОЇ ОСВІТИ}

\begin{abstract}
У наш час, коли національні чинники зумовлюють розвиток освітянської справи, не викликає сумніву необхідність грунтовного опрацювання надбань українського мистецтва у вищій школі. У статті розглянуто змістовні характеристики розвитку естетичної культури студентів у закладах вищої освіти, що зумовлюють гармонізацію національного і міжкультурного підходу до опанування українського мистецтва. Окреслено художні переваги творів українських авторів, що впливають на активізацію естетичного сприймання, оцінку, творчу інтерпретацію у навчально-виховному процесі. У статті проаналізовано способи впливу українського мистецтва на розвиток естетичної культури студентів у закладах вищої освіти: творче опанування надбань національної художньої культури, що передбачає застосування художньо-порівняльних підходів як шлях отримання теоретичних відомостей про твори українських митців; пізнання стильових засад українського мистецтва в системі усвідомлення студентами образного мислення українських авторів; національно-вартісна орієнтація естетичного самовизначення студентів, що дозволяє оцінювати світову культуру через призму національного бачення, зберігати і розповсюджувати цінності українського мистецтва. Зазначено, що фундаментальною проблемою педагогічного забезпечення процесу пізнання творів національного мистецтва $\epsilon$ визначення естетичних орієнтирів відбору художнього матеріалу, в процесі опрацювання і засвоєння якого має відбуватись естетичний розвиток особистості. Моделювання діяльності викладача передбачає різноманітні пошукові завдання в галузі інтерпретації, що опосередковуються його естетичними орієнтирами, спонукання студентів до якомога ширшого осягнення художніх надбань українського мистецтва та подолання нейтрального до них ставлення. У статті визначено сутність історико-стильового підходу, який дозволив проаналізувати художні стилі на історичній основі. Фольклорна семантика, образні засади виразової героїчної тематики, що визначають своєрідність українського мистецтва, створюють умови для виникнення ефекту співпереживання змісту художніх творів.
\end{abstract}

Ключові слова: естетико-виховний потенціал, національна ідентичність, стильові засади, історико-стильовий підхід.

Постановка проблеми. Сьогодні національні чинники відіграють все більшу роль у художньому житті країни, цілком очевидною постає необхідність якомога ширшого ознайомлення студентів із здобутками українського мистецтва в закладах вищої освіти. В контексті нашого дослідження набуває актуальності питання про значення національних особливостей мистецтва, зокрема у визначенні педагогічних засобів впливу на розвиток естетичної культури особистості.

У Законі України «Про вищу освіту» від 05. 09. 2017 p. № 2145-VIII щодо формування і peaлізації державної політики у сфері вищої освіти наголошено, що гармонійна взаємодія національних систем освіти, науки, мистецтва, бізнесу та держави забезпечує стійкий соціально- економічний розвиток держави [Закон України «Про вищу освіту]. У Концепції національнопатріотичного виховання в системі освіти України від 29.07.2019 р. № 1038 обгрунтовано принципи національної спрямованості, полікультурності, історичної і соціальної пам'яті, що передбачають формування національної самосвідомості, здатності зберігати свою національну ідентичність, пишатися належністю до українського народу, спроможності сприймати українську культуру як невіддільний складник культури загальнолюдської [Концепція національно-патріотичного виховання в системі освіти України].

Аналіз попередніх досліджень. В українській естетиці підходи до осмислення мистецтва як художнього виміру людського буття, 
зокрема в національних його вимірах, досліджували вчені В. Іванов, В. Мазепа, Л. Шеремет, Н. Яранцева та інші. Окремі аспекти розвитку естетичної культури студентської молоді в процесі професійної освіти проаналізовано у працях Л. Левчук, В. Дряпіки, О. Отич, Г. Падалки, О. Рудницької, О. Шевнюк, де грунтовного опрацювання дістали проблеми формування духовного потенціалу студентів, формування ïx естетичного сприймання та естетичних ідеалів і смаків. Концептуальні ідеї, що сприяють вирішенню проблем розбудови національної вищої школи, розвитку навчання і виховання, містяться в роботах психологів Н. Ануфрієвої, I. Беха, Г. Костюка, Т. Яценко та інших. Теоретичні аспекти культури і культурного розвитку людини засобами мистецтва глибоко опрацьовано в роботах І. Зязюна, Н. Крилової, В. Кудіна, А. Щерба та інших. Однак і сьогодні лишається багато невизначених аспектів проблеми естетичного розвитку особистості в контексті національної культури. Відсутні дослідження, спрямовані на виявлення механізмів впливу національного мистецтва на естетичні погляди, орієнтири естетичної оцінки студентської молоді, мало уваги приділяється вивченню принципових шляхів та різноманітних форм і методів пізнання студентами творів українських авторів.

Мета статті - проаналізувати естетиковиховний потенціал українського мистецтва, розкрити особливості його впливу на розвиток естетичної культури студентів закладів вищої освіти, визначити сутність історико-стильового підходу до пізнання національного мистецтва як особистісної світоглядної позиції.

Виклад основного матеріалу. Аналіз наукової літератури свідчить про багатомірність підходів до визначення естетичної культури. $\mathrm{y}$ дослідженнях вчених естетична культура особистості виступає як зорієнтованість їі естетичної діяльності не на предмети і явища самі по собі, а на те, як зображуються їх внутрішні якості у їх зовнішній формі [Лутаєнко : 112]. Необхідного спрямування набуває естетична культура, коли вона постає як здатність правильно відчувати і розуміти прояви естетичного в навколишній дійсності, різноманітній діяльності людини, зокрема в мистецтві, а також як прагнення до прекрасного, до естетичного самовдосконалення, до творчості за законами краси Ільїн: 83-99]. Педагогічні аспекти підкреслено у визначенні, де естетична культура розглядається як результат свідомо-організованого впливу на внутрішній світ людини з метою розвитку у неї почуття прекрасного, вміння бачити i насолоджуватись красою природи, творів літератури і мистецтва, давати вірну естетичну оцінку мистецьким творам, вчинкам людей, предметам побуту та інші, відрізняти прекрасне від не естетичного [Побережна].

Ряд авторів естетичну культуру трактує як похідну від усвідомлення мистецтва. Так, Г. Нестеренко пропонує визначити естетичну культуру як «сукупність емоційних і творчих здібностей, сформованих засобами мистецтва i спрямованих на активне перетворення дійсності [Нестеренко : 64]». 3 позицій ставлення до мистецтва розкриваються поняття особистісної художньої культури як рівня спроможності розуміти мистецтво, відчувати його, насолоджуватись досконалістю художнього відображення та прагнення до участі в художній творчості, прилученні до художньо-творчої діяльності. Л. Побережна трактує естетичну культуру як інтегровану якість особистості, що $є$ основою здатності її до сприймання і оцінки прекрасного, потворного, високого i низького, трагічного і комічного в дійсності, а також до іiі перетворення «за законами краси» [Побережна : 9].

Основою розвитку естетичної культури студентів засобами українського мистецтва виступає впровадження у навчально-виховний процес пізнання стильових засад національного мистецтва, що дозволяє студентам сприйняти українське мистецтво як складник світової художньої культури, а також глибоко проникнути у національну своєрідність індивідуального творчого почерку українських митців.

Естетичні виміри мистецтва зумовлюються не тільки художнім багатством образного змісту, а і стилістичними закономірностями форми, що органічно зливається з ним. Сдність змісту i форми художньо-образного відтворення дійсності - закономірність, притаманна справжньому, високому мистецтву. Національний характер образного строю не може бути повноцінно розглянутий без осмислення національних характеристик художніх закономірностей форми. 
Цінності українського мистецтва значною мірою визначаються різноманітністю художньо-образного відтворення світу. Духовногуманістична спрямованість кращих здобутків національного мистецтва знайшла відображення в перебігу широкої гами різнобарвних почуттів, найтонших їх нюансів. Загалом українське мистецтво вписало яскраву змістовну сторінку в історію світової художньої культури.

Історико-стильовий підхід виступає як дійовий чинник пізнання українського мистецтва і надає можливість послідовної кристалізації в свідомості студентів характерних ознак творів українських митців, систематизації знань студентів, визначення ролі і місця творчої спадщини автора в загальному розвиткові мистецтва. Застосування історико-стильового підходу дозволяє студентам усвідомлювати цілісний рух розвитку стильових ознак українського мистецтва. Виявлення окремих рис у творчості українських митців набуває упорядкованого характеру.

У контексті нашого дослідження заслуговують увагу специфічні способи впливу українського мистецтва на естетичний розвиток студентів у вищих закладах освіти: творче опанування надбань національної художньої культури, пізнання стильових засад українського мистецтва, національно-вартісна орієнтація естетичного самовизначення студентів. Розглянемо їх послідовно.

Творче опанування надбань національної художньої культури. Систематизація дослідницького пошуку відбувалась шляхом співвіднесення завдань естетичного розвитку студентів 3 художніми характеристиками творів українського мистецтва на основі визначення специфічних особливостей і аналізу мистецьковиражальних засобів. Національному художньо-образному мисленню українських митців притаманний ліризм, поетизація світобачення, найтонші нюанси внутрішнього буття людини, вираження різноманітності почуттів. Гуманістично-змістовні пласти українського мистецтва великою мірою визначено саме підвищеною увагою до людських емоцій, глибинною проникністю до світу внутрішніх іiі переживань. Розглядаючи психофізіологічні та соціальні особливості українського народу, які мають специфічний зміст і форму, Л. Шеремет серед чинників естетичного світобачення українців висуває екофільність, схильність до підкресленого емоційно-естетичного сприйняття природи, своєрідного злиття 3 нею в естетичних вимірах життя [Шеремет : 154].

До типових характеристик українського мистецтва слід віднести образно-узагальнене відбиття найрізноманітніших людських переживань, психологічно рельєфне окреслення широкої палітри емоційних станів від бурхливобентежних до філософсько-заглиблених образів, від героїчно-піднесених до меланхолійноелегійних. Експресивну відкритість образного змісту творів українських митців втілено в розмаїтому колі жанрових підходів. Серед естетичних переваг національно-стильових факторів слід назвати такі, як врівноваженість застосування музично-виражальних засобів і їх відповідність образному змісту твору. В сучасній естетиці і мистецтвознавстві намітилась лінія аналізу, що розглядає змістовне наповнення мистецтва залежно від усвідомлення узагальнених рис, соціально-психологічних ознак народного характеру, від національної ментальності. Наголошується, що умови життєдіяльності певного народу мають вплив на вироблення національних особливостей художньої культури цього народу і водночас сприяють виробленню у нього певних смаків, уявлень і критеріїв оцінки творів мистецтва [Шеремет : 75]. Важливим надбанням національного мистецтва є також образи, сповнені героїчно-піднесеного драматичного настрою. 3 естетичними ідеалами романтизованої боротьби пов'язано безліч творів, які можуть стати неоціненним матеріалом для розвитку естетичної культури студентів у закладах вищої освіти.

Пізнання стильових засад украйнського мистецтва. Дослідження стильових засад опрацювання студентами творів українського мистецтва має відбуватись у межах сучасної філософської мистецької освіти і передбачати створення відкритої системи взаємодії між художнім змістом мистецького збагачення студентів на подальшу розбудову національної культури. Означена проблема грунтувалась на таких положеннях:

- визначення стилю як системи художньої виразності, засобів і прийомів, що зумовлено єдністю естетичного та суспільно-історичного змісту; 
- визнання існування різних рівнів прояву функцій стилю: стиль епохи, стиль напряму, стиль авторський, стиль національний;

- діалектика взаємодії спільного і окремого, узагальненого і особливого у становленні стилю і стильових традицій національних мистецьких шкіл.

До опрацювання стильових засад українського мистецтва у навчально-виховному процесі віднесено: систематизацію мистецьких творів за історичними ознаками, спонукання студентів до емоційного співпереживання творів українського мистецтва; обгрунтування стильових ознак творів шляхом порівняльних підходів; визначення авторського стилю в різних видах мистецтва.

Широке ознайомлення студентів 3 творами українського мистецтва має поєднуватись із певним класифікаційним підходом. М. Каган справедливо підкреслює, що художня освіченість - це не просто ерудованість, не формальне знання історії мистецтва, а передусім знання багаточисленних видових і стильових систем художньо-образних знаків, що дозволяють легко і вільно розуміти виражену з їх допомогою поетичну інформацію [Каган :334].

Національно-вартісна орієнтація естетичного самовизначення студентів. Національно-вартісна орієнтація навчально-виховного процесу трактується в нашому дослідженні як важливий чинник розвитку естетичної культури студентів. Високий рівень їх професійної підготовки передбачає схильне, шанобливе ставлення до вітчизняної культури, оцінювання світової культури через призму національного бачення, прагнення до вивчення, збереження і розповсюдження цінностей українського мистецтва. Національно-вартісна орієнтація навчально-виховного процесу досягається на основі різнобічних знань студентів у галузі українського мистецтва. Це важлива, необхідна, але не достатня умова, коли йдеться про внутрішнє, особистісне спрямування ціннісних установок студентів на українське мистецтво. Якщо надбання національного мистецтва не входять у систему особистісних цінностей студента, годі вважати успішним вирішення естетико-виховних завдань навчання.

Важливою умовою впровадження мистецько-творчих завдань $є$ урахування індивідуальних можливостей студентів. Експериментальне дослідження виявило широкий діапазон індивідуальних відмінностей як за рівнем творчого потенціалу, так і за якісно змістовними характеристиками студентів. Цілий ряд студентів відчував ускладнення в зв'язку з відсутністю творчого досвіду. В кожному разі підтримка творчих спроб, тактовний аналіз і зауваження - неодмінні супутники педагогічного стимулювання студентів до творчості.

Педагогічне забезпечення національно-вартісної орієнтації включає послідовне розширення спонукальних чинників, оцінювальних дій студентів і передбачає індивідуально-естетичні уподобання студентів та об'єктивізацію оцінювальної позиції студентів щодо національного мистецтва.

Підкреслюючи необхідність формування у студентів національних орієнтирів естетичної оцінки, зауважимо, що вибірково спрямовану діяльність естетичної свідомості, підпорядковану завданням національного самовизначення, важливо узгоджувати із виявленням місця українського мистецтва в системі розвитку світової художньої культури. Замикання в національній культурі не тільки обмежує мистецький кругозір, а й спричиняє серйозні перекоси в естетичних поглядах майбутніх вчителів музики. Інтегративні процеси в розвитку світової і національної художніх культур очевидні і об'єктивні. Прагнення до визначення національно-естетичної специфіки вітчизняного мистецтва не суперечить діалогу між різними культурами. Отже, національно-вартісна орієнтація навчальновиховного процесу не тільки не заперечує, a i передбачає ознайомлення студентів із здобутками світової художньої культури.

Висновки. Художньо-педагогічний аналіз і розгляд українського мистецтва як естетикоузагальнюючого явища дозволив визначити непересічні художні цінності національного мистецтва, що становлять невіддільну частину світової художньої культури. Характеристики естетичної культури в наведеному ракурсі із виокремленням пріоритетно-типових напрямів у розмаїтій палітрі художньо-образних надбань українського мистецтва дають можливість стверджувати, що мистецтво українського народу, застосоване в педагогічній практиці, може особливим чином вплинути на спрямування естетичного ставлення студентів до життя і майбутньої професії. 


\section{ЛІТЕРАТУРА}

1. Закон України «Про вищу освіту» від 05. 09. 2017 р. № 2145-VIII

2. І Ільїн В. В. Культура і творчість. Деякі аспекти формування національної культури студентської молоді: зб. наук. пр. Київ, 1997. С. 83-99.

3. Каган М. С. Морфология искусства. Историко-теоретическое исследование внутреннего строения мира искусств. Искусство. 1972. № 1-3. 440 с.

4. Концепція національно-патріотичного виховання в системі освіти України від 29.07.2019р. № 1038

5. Лутаєнко В. С. Естетика мистецтва як фактор формування творчого мислення. Либідь, 1992. 132 с.

6. Нестеренко Г. П. Формирование музыкально-эстетической культуры студентов. Совериенствование подготовки учителя нач. классов с доп. спеи. Минск. 1984. С. 63-65.

7. Побережна Л. Л. Розвиток естетичної культури студентів музично-педагогічних факультетів засобами української музики: автореф. ...канд. пед. наук: 13.00.02. Київ, 2001. 21 с.

8. Шеремет Л. П. Особистість і культура в аспекті нового мислення. Біла Церква. 1998. 230 с.

\section{REFERENCES}

1. Zakon Ukrainy "Pro vyshchu osvitu" vid 05. 09. 2017 r. № 2145-VIII

2. Ilin V. V. (1997) Kultura i tvorchist. [Culture and creativity]. Some aspects of the formation of the national culture of student youth P. 197-206 [in Ukrainian]

3. Kagan M. S. (1972) Morfologiya iskusstva. Istoriko-teoreticheskoe issledovanie vnutrennego stroeniya mira iskusstv. [Morphology of art. Historical and theoretical study of the inner structure of the art world]. Art. no. 1-3. [In Russian]

4. Kontseptsiia natsionalno-patriotychnoho vykhovannia v systemi osvity Ukrainy vid 29.07.2019 r. № 1038

5. Lutaienko V. S.(1992) Estetyka mystetstva yak faktor formuvannia tvorchoho myslennia.[ Aesthetics of art as a factor in the formation of creative thinking]. Lybid. [in Ukrainian]

6. Nesterenko H. P. (1984) Formyrovanye muzykalno-estetycheskoi kultury studentov. [Formation of musical and aesthetic culture of students] Improving teacher training classes with extra special. Minsk. Pp. 63-65 [in Belarus]

7. Poberezhna L.L. (2001) Rozvytok estetychnoi kultury studentiv muzychno-pedahohichnykh fakultetiv zasobamy ukrainskoi muzyky [Development of aesthetic culture of students of music and pedagogical faculties by means of Ukrainian music]: author's ref. dis. ... cand. ped. sciences: 13.00.02. Kyiv. 21 p. [in Ukrainian]

8. Sheremet L.P. (1998) Osobystist i kultura v aspekti novoho myslennia. [Specialty and culture in the aspect of the new mission] Bila Tserkva. 230 p. [in Ukrainian]

\section{L. ORDINA}

Candidate of Pedagogical Sciences,

Associate Professor at the Department of Social Humanitarian Disciplines,

Bila Tserkva National Agrarian University,

Bila Tserkva, Kiev region, Ukraine

E-mail: Larisaordina@ukr.net

http://orcid.org/0000-0003-4127-6225

\section{THE INFLUENCE OF UKRAINIAN ART ON THE DEVELOPMENT OF AESTHETIC CULTURE OF STUDENTS IN HIGHER EDUCATION INSTITUTIONS}

Nowadays, when national factors determine the development of education, there is no doubt about the need for thorough study of the achievements of Ukrainian art in higher education. The article considers the substantive characteristics of the development of aesthetic culture of students in higher education institutions, which determine the harmonization of national and intercultural approach to mastering Ukrainian art. The artistic advantages of the works of Ukrainian authors that influence the activation of aesthetic perception, evaluation, creative interpretation in the educational process are outlined. The article analyzes the ways of influence of Ukrainian art on the development of aesthetic culture of students in higher education: creative mastery of national art culture, which involves the use of artistic and comparative approaches as a way to obtain theoretical information about the works of Ukrainian artists; knowledge of the stylistic principles of Ukrainian art in the system of students' awareness of figurative thinking of Ukrainian authors; national-value orientation of aesthetic self-determination of students, which allows to evaluate world culture through the prism of the national vision, to preserve and disseminate the values of Ukrainian art. It is noted that the fundamental problem of pedagogical support of the process of cognition of works of national art is the definition of aesthetic guidelines for the selection of artistic material, in the process of elaboration and assimilation of which the aesthetic development of personality should take place. Modeling the teacher's activity involves a variety of search tasks in the field of interpretation, mediated by his aesthetic guidelines, encouraging students to the widest possible understanding of the artistic heritage of Ukrainian art and overcoming a neutral attitude towards them. The article defines the essence of the historical-stylistic approach, which allowed to analyze artistic styles on a historical basis. Folklore semantics, figurative principles of expressive heroic themes, which determine the originality of Ukrainian art, create conditions for the emergence of the effect of empathy for the content of works of art.

Key words: aesthetic and educational potential, national identity, stylistic principles, historical and stylistic approach. 